\title{
Social Safety Net Programs: Contribution to Socio-Economic Resilience of Vulnerable Group
}

\author{
Irteja Hasan' ${ }^{1}$ (D) \\ Israt Sultana ${ }^{2}$ (D) \\ Ali Adnan ${ }^{3}$ \\ Md. Delwar Hossain ${ }^{4}$ \\ Md. Abdur Rouf Talukder ${ }^{5}$ \\ Md. Tareq Jubayer ${ }^{6}$ \\ Md. Mostafizur Rahman ${ }^{7}$ \\ Md. Sagirul Islam Majumder ${ }^{8} \nless$ \\ ${ }^{1,2}$ Bangladesh Coastal Development Foundation, Bangladesh \\ 'Email:irteja07@gmail.com \\ ${ }^{3}$ Department of Emergency Management, Patuakhali Science and Technology University, Dumki, \\ Patuakhali, Bangladesh \\ Email:adnan.kushtia@gmail.com \\ ${ }^{4,5}$ Department of Civil Service, People's Republic of Bangladesh, Dhaka, Bangladesh \\ EEmail:delwar_h@yahoo.com \\ ${ }^{5}$ Email: roufbabu@gmail.com \\ ${ }^{\circ}$ Department of Bangladesh Police, People's Republic of Bangladesh, Dhaka, Bangladesh \\ ${ }^{6}$ Email: tareq_jubayer@yahoo.com \\ Institute of Education and Research, university of Dhaka, Dhaka, Bangladesh. \\ 'Email:mostafizdu1995@gmail.com \\ ${ }^{8}$ The United Graduate School of Agricultural Science, Kagoshima University, Japan \\ ${ }^{5}$ Email:sagir_mjd@yahoo.com
}

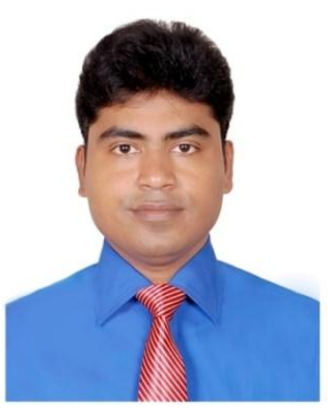

( Corresponding Author)

\begin{abstract}
Bangladesh is a disaster affected country due to its geographical location and anthropogenic causes. Every year thousands of people are impacted by different kinds of climate induced environmental stressed. Social Safety Nets (SSNs) are non-contributory programmes that helps the poor and vulnerable community and also to reduce poverty and inequality to cope with disasters. Bangladesh government has taken initiative to alleviate poverty including the most vulnerable segment and poor people under different Safety Net Programmes. This study has been undertaken to assess the impacts of these allowance programs for increasing social and economic resiliency in household level. Both primary and secondary data were used to conduct this study. Primary data were collected through questionnaire survey, focus group discussions, and case study. Secondary data were collected from different sources including books, journals and websites related to the study. This study has also investigated how the allowance allocated to extreme poor widows, elders and disabled people can facilitate their disaster resiliency. It compares the situation of allowance receivers to the situation when they were not getting the allowance. The study found that the program has a positive impact on the basic needs like food, cloth, medicine accessibility of the beneficiaries which make them economically resilient. It also founds that although the allowance amount is relatively small and insufficient to significantly contribute to household's graduation, it often enables recipients to stabilize their earnings. The study has suggested the need to develop a number of strategies especially for the local government to facilitate successful SSN program including increasing the amount of allowance, distributing money through mobile banking system, proper monitoring in selection process are most urgent in the study area.
\end{abstract}

Keywords: Social Safety Net Program, Vulnerable Group, Resiliency, Bangladesh. 
Citation | Irteja Hasan; Israt Sultana; Ali Adnan; Md. Delwar Hossain; Md. Abdur Rouf Talukder; Md. Tareq Jubayer; Md. Mostafizur Rahman; Md. Sagirul Islam Majumder (2018). Social Safety Net Programs: Contribution to Socio-Economic Resili Social Asian Journal of Social Sciences and Management Studies, 5(3): 105-113.

History:

Received: 19 February 2018

Revised: 1 June 2018

Accepted: 5 June 2018

Published: 8 June 2018

Licensed: This work is licensed under a Creative Commons

Attribution 3.0 License (oc)

Publisher:Asian Online Journal Publishing Group
Contribution/Acknowledgement: All authors contributed to the conception and design of the study.

Funding: This study received no specific financial support.

Competing Interests: The authors declare that they have no conflict of Competing

Transparency: The authors confirm that the manuscript is an honest, accurate, and transparent account of the study was reported; that no vital features of the study have been omitted; and that any discrepancies from the study as planned have been explained.

Ethical: This study follows all ethical practices during writing

\section{Contents}

1. Introduction

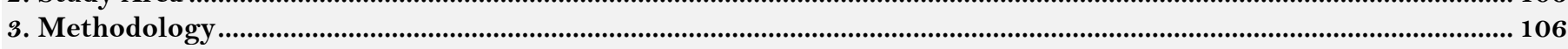

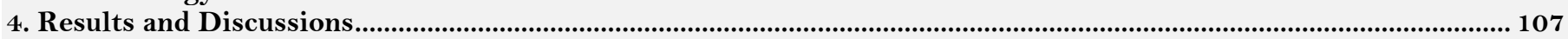

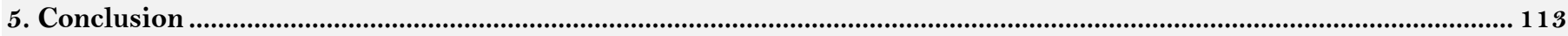

References...

\section{Introduction}

Social Safety Net Programmes (SSNPs) are such kind of public measures, which government of private organization provides for its members to protect them from various types of economic and social needs (Khuda, 2011). Social Safety Net Programmes are considered to be an effective measure for reducing poverty for a developing country like Bangladesh (Begum and Akter, 2014); (Khan, 2012). It is found that around 15 percent of the government expenditure in Bangladesh in 2010 (Barkat et al., 2011). The extreme poor households are often considered a challenging target group for mainstreaming to development interventions. These households are often characterized by low education levels, low levels of land ownership, social exclusion and disempowerment (World Bank, 2008). Their subsistence generally relies on their daily labour and fluctuating earnings more than on revenues from assets (Ahmed, 2005); (Hies, 2010). The group under study experiences multiple hazards which increase their vulnerability and threatens their well-being. Cyclone, for example, significantly pushes extreme poor people under lower poverty line (Uddin, 2013); (Ahrc, 2010).

Program for old, widow and disable are the most important programmes dealing with the most vulnerable, marginalized section of the population (Khan, 2012); (Mazmanian and Sabatier, 1981). Considering the realities and sufferings of these groups with the intention to reduce their vulnerability, the government of Bangladesh took initiative for their social protection and security under the Ministry of Social Welfare. The major objectives of this program are to strengthen the mental force of these vulnerable persons, increase their status in the family and society and bring back their sense of security in the society through unconditional cash transfer (Maniruzzaman, 2009). There have an ample scope to conduct research on the impact of these allowance schemes in Bangladesh (Mannan and Ahmed, 2012). Therefore, this study concentrates on to assess the impact for the old, widow and disable allowance program for selected beneficiaries in the study area. This qualitative study also investigates whether Social Safety Net contribute to building resilience of vulnerable extreme poor beneficiaries

\section{Study Area}

In this study, at first Laokhati Union of Patuakhali district was selected purposively on the basis of economic condition and vulnerability. As the allowance program was aimed to bring welfare and improvement of quality of life of the vulnerable elderly persons. This union is poor area what is typically agriculture based backward union. The communication system is also very poor. Most of the people live with disaster risks where this initiative can play a vital role in aspect of increasing resiliency.

\section{Methodology}

The study relied upon both quantitative and qualitative methods for conducting the research. The study has generally depended on interviews, surveys and case study methods. FGDs were also conducted with relevant stakeholders. The study has included interviewing some of the government officials, local representatives and key informants to have in depth idea of the area under study. The questions were both open and close ended. Closed ended questions were used to save time and open ended questions were used to have in-depth knowledge and insight of the respondents. Questionnaire survey method was used to gather primary data directly from the beneficiaries and those officials who were directly related with implementation process and this helped to get information which was very much helpful in the study. Case study method was used in this study to explore some important issues. This analysis include collecting related information and data from all relevant government documents, important office documents, circulars, books, published and unpublished research works available, online articles etc. Focus Group Discussion (FGD) method was used to have in-depth understanding of the selection process. Lots of interesting and important findings came out in the discussion. The facts that came out helped to validate information of other methods. Among the respondents the 120 beneficiaries were selected on a 
purposive basis who got support from government or different NGO/INGO. The data has been processed by placing into various diagrams or charts. For statistical tests and analysis MS Excel has been applied. Finally, results with summary and conclusion have been presented.

\section{Results and Discussions}

\subsection{Allowance Months and Seasonal Income Variation}

Allowance distribution months and seasonal variation analyzes that the month of Ashar (Jun-July) is the starting month of the monsoon period which is regarded as the unproductive season. In this month they buy daily needs on credit with the hope of repaying after receiving an allowance. So they use the allowance money to repay the credit amount and buy mostly rice for the current and following month of Bhadro. A beneficiary of old age allowance living with his wife and granddaughter said, "In rainy season there is always scarcity of work. With this allowance, I will repay the last month's credit of BDT 400 for buying rice and will buy rice with BDT 400 for the next month." As a result, the allowance money is supporting to cope with the income crisis of the monsoon season. It was found that the third quarter of the year was also regarded as lean period as there are limited income opportunities in the agricultural fields. During the later month of this quarter, production starts which will be harvested in the first quarter of the year. Besides managing consumption needs, other few uses of allow ance were found in these two quarters buying medicine, children's books etc.

The fourth quarter was found to earn from other income sources as stated earlier in the livelihood Section. Besides repaying credit or maintaining regular expenditure, they are able to invest the money to repair their house or support their daughter's family or buy more assets. One of the independent old age allowance recipients who used to beg in the surrounding village to maintain his family expenses said, "I started receiving allowance about a year ago. Before receiving allowance, my house was totally damaged and was unable to stay there. After receiving the allowance in the month of Magh, I planned to repair the shed. With the first two installments of allowances, I rebuilt the roof after last Boishak."

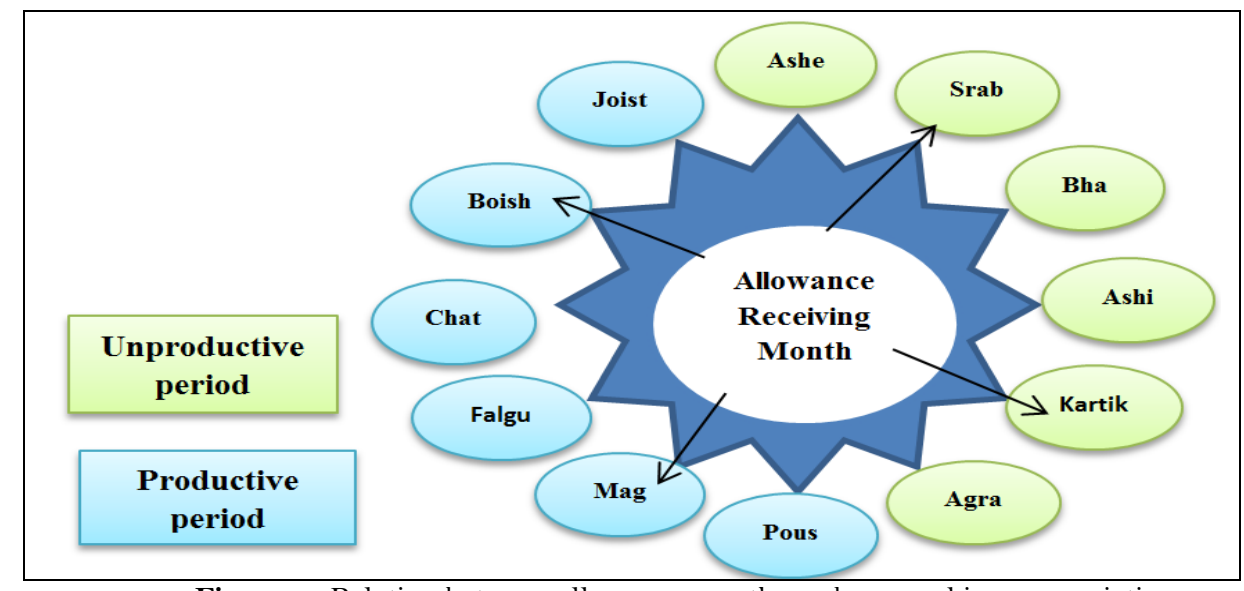

Figure-1. Relatior
(Source: Field Survey, 2018).

\subsection{Food Intake by the Respondents}

\subsubsection{Daily Food Intake Pattern}

The program has positive impact on daily food intake pattern. The study found that that maximum respondent's intake three times food daily after receiving the allowance specially the disables (Figure 2). It indicates that now the vulnerable communities are able to meet their basic need by this program.

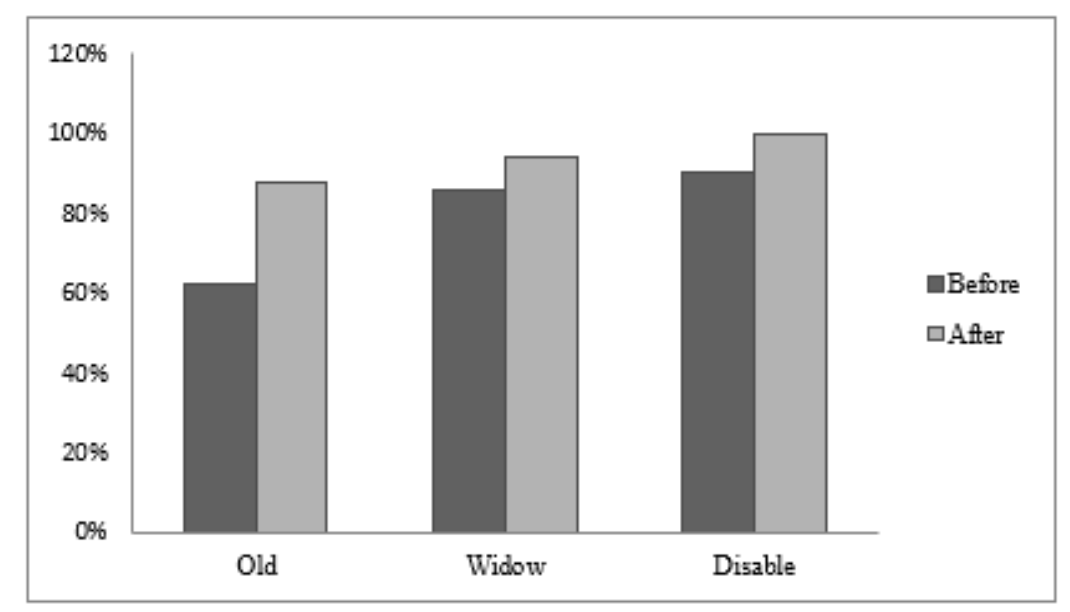

Figure-2. Daily food intake pattern of various respondents (Source: Field Survey, 2018). 


\subsubsection{Intake Other Foods than Rice}

Before receiving the allowance, very few respondents have the ability to take any other foods (like biscuit, cake) than rice. Now by this allowance, they are being able to buy various household goods which help to improve their social status in the community. So this percentage has improved up after receiving the allowance (Figure 3 ).

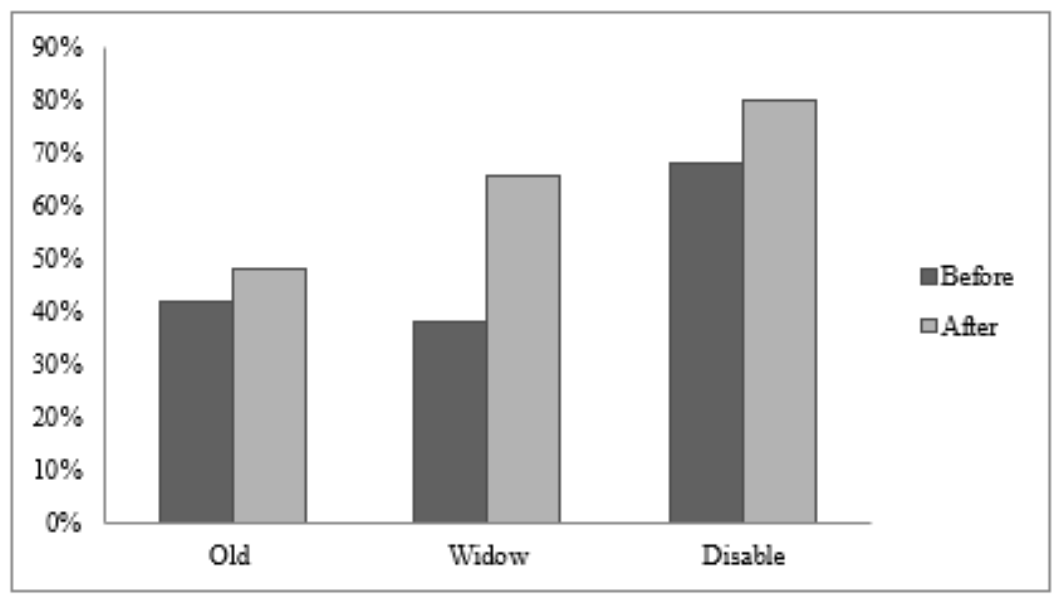

Figure-3. Intake other food then rice of the respondents

(Source: Field Survey, 2018).

\subsubsection{Rice Borrowing}

Before receiving the allowance the economic condition of these beneficiaries was so poor. They have to borrow rice or other foods once or twice in a month from near shops or neighbors. Even 68 percent of old needed to borrow rice (Figure 4) to fulfill their family demand. But after receiving the allowance the most of the respondents have no need to borrow rice. So, now they are being self-resilient and ultimately this program uplifts their socioeconomic condition.

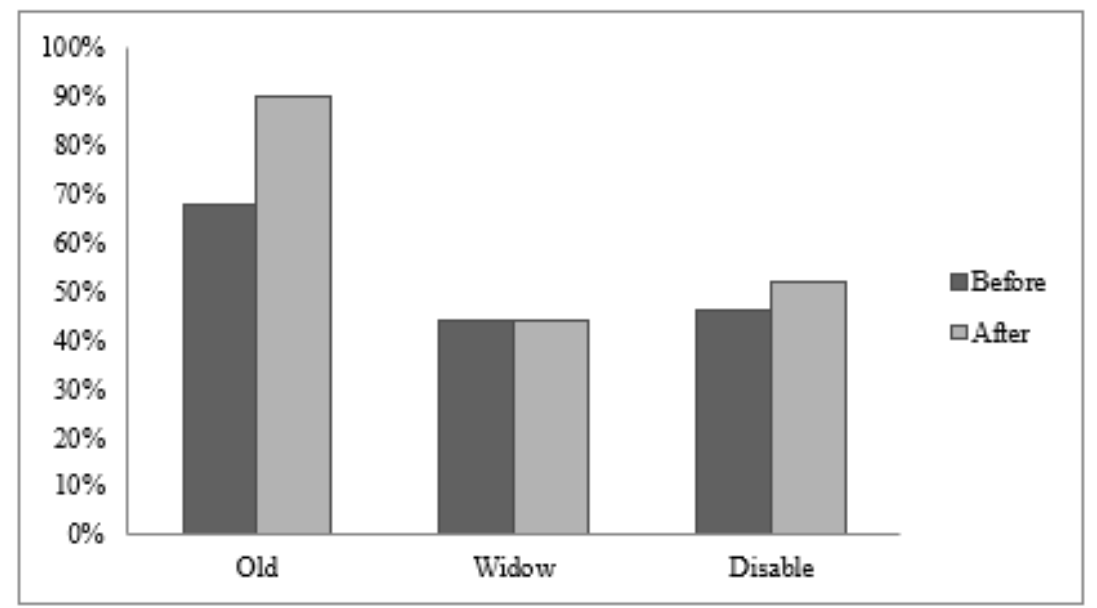

Figure-4. Rice borrowing status of the respondents

(Source: Field Survey, 2018).

\subsubsection{Programme Effectiveness on Food Items}

Before intervention the program it was quite tough for the poor people to manage three times meal in a day where quality and quantity are. But now they consider these issues also. From the Figure 5 it is observed that both the quality and quantity of food of the respondents has improved due to program intervention. So, of course it has positive impacts on the community in aspects of poverty to solvency.

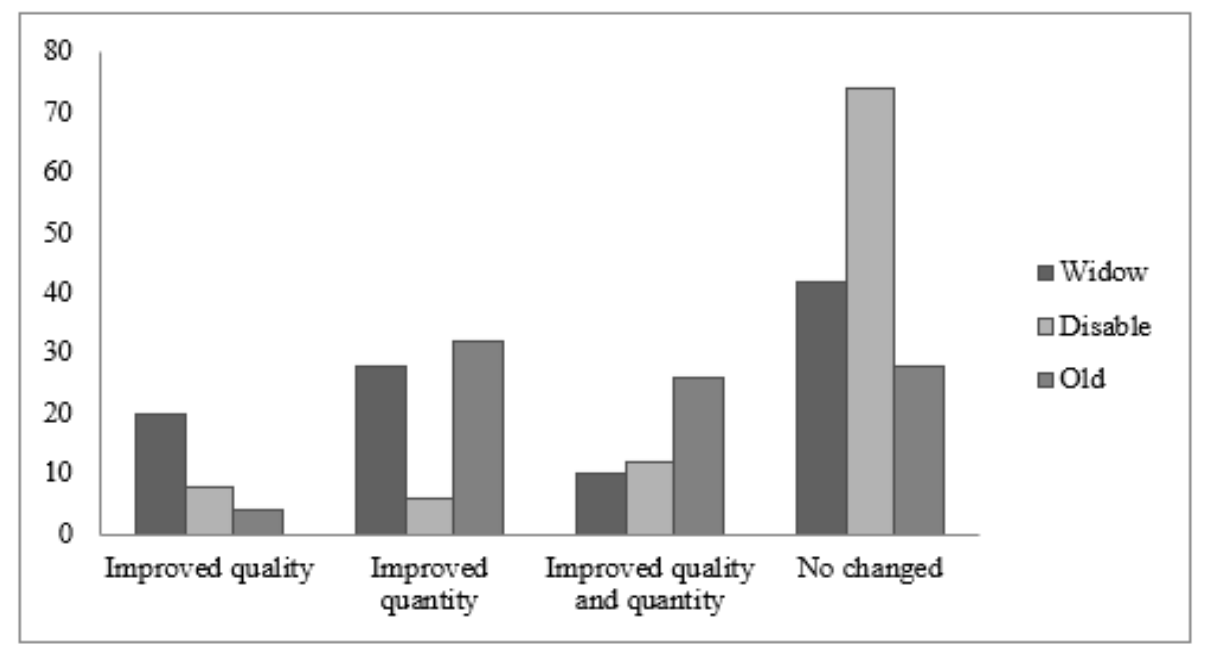

Figure-5. Program effectiveness on food items of the old respondents (Source: Field Survey, 2018). 


\subsection{Access to Health Facilities}

\subsubsection{Purchase of Medicine}

Before receiving the allowance the beneficiaries met their necessary medicine with the help of others. In case of after receiving the allowance, most of the respondents have purchased their necessary medicine by own cost specially the old (Figure 6) where the percentage was 30 before receiving the allowance. The number of beneficiaries who took financial support from family members also has been reduced which indicate that now they became self-dependent. Even now they no need to borrow from kith and kin.

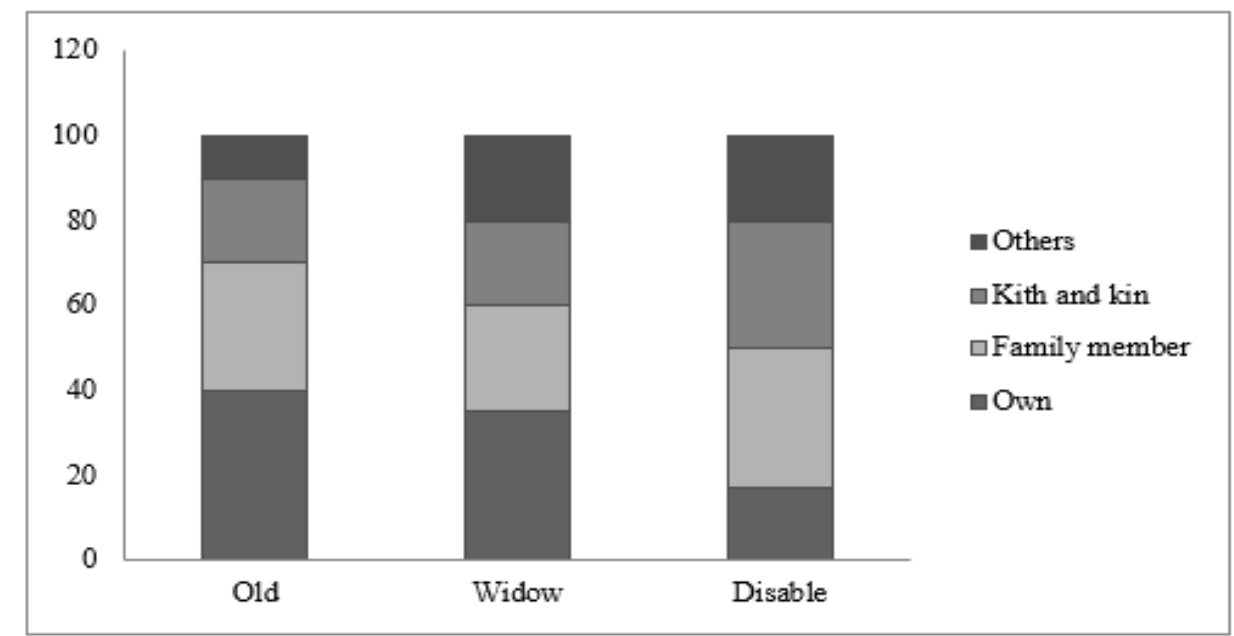

Figure-6. Purchase of medicine status of the old respondents

(Source: Field Survey, 2018)

\subsubsection{Sources of Money}

From the figure it is understood that most of the beneficiaries can meet their necessary medicine by their own cost by the program. Before intervention the programme it was a matter of worry that who will serve the money for their medical treatment. Maximum times they didn't get proper service and as a result they had to suffer for this. But now this little amount makes them a little bit happy.

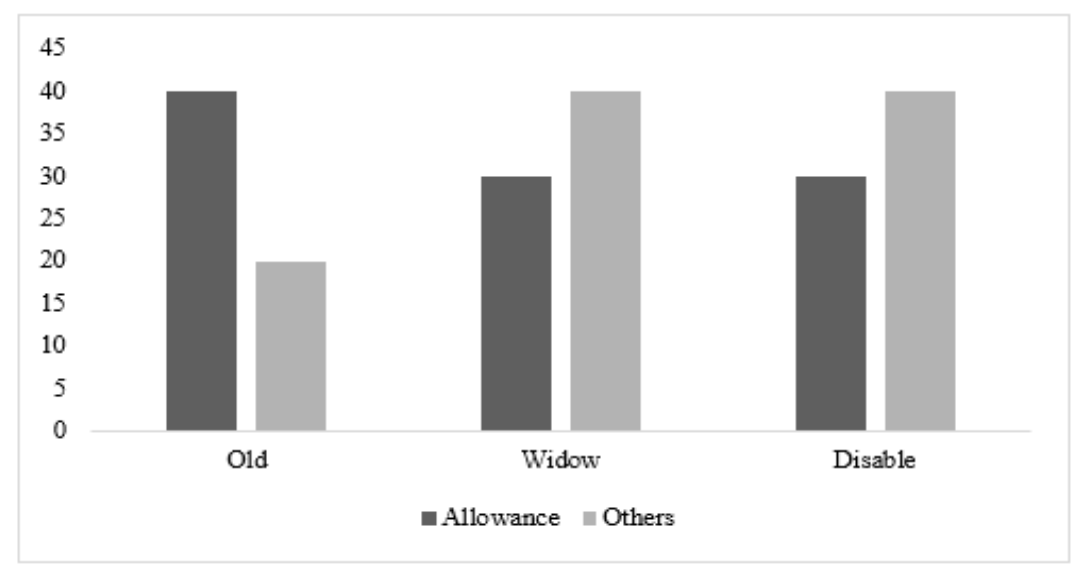

Figure-7. Source of money for medical treatment status of the respondents (Source: Field Survey, 2018).

\subsection{Affordability of Clothes}

\subsubsection{Purchase of Clothes}

Before getting the grant the recipients get there cloth with the help of others like zakat and sometimes by owns those who have ability to buying and the amount was very few. But after engaging the program, number has been increased. The number of recipient who took provision from other sources has been reduced.

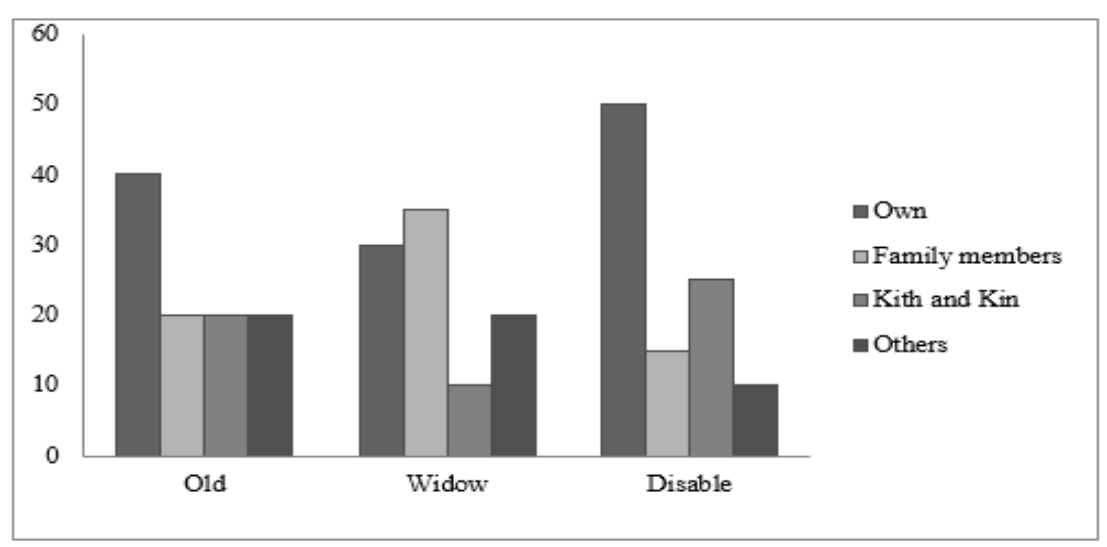

Figure-8. Purchase of cloth status of the old respondents (Source: Field Survey, 2018). 


\subsubsection{Sources of Money}

It is realized that most of the beneficiaries have met their necessary cloth by their own charge. From the Figure 9 it is seen that most of the respondents rely of allowance for buying cloth. Through the percentage was no so high but it is positive sign for any community.

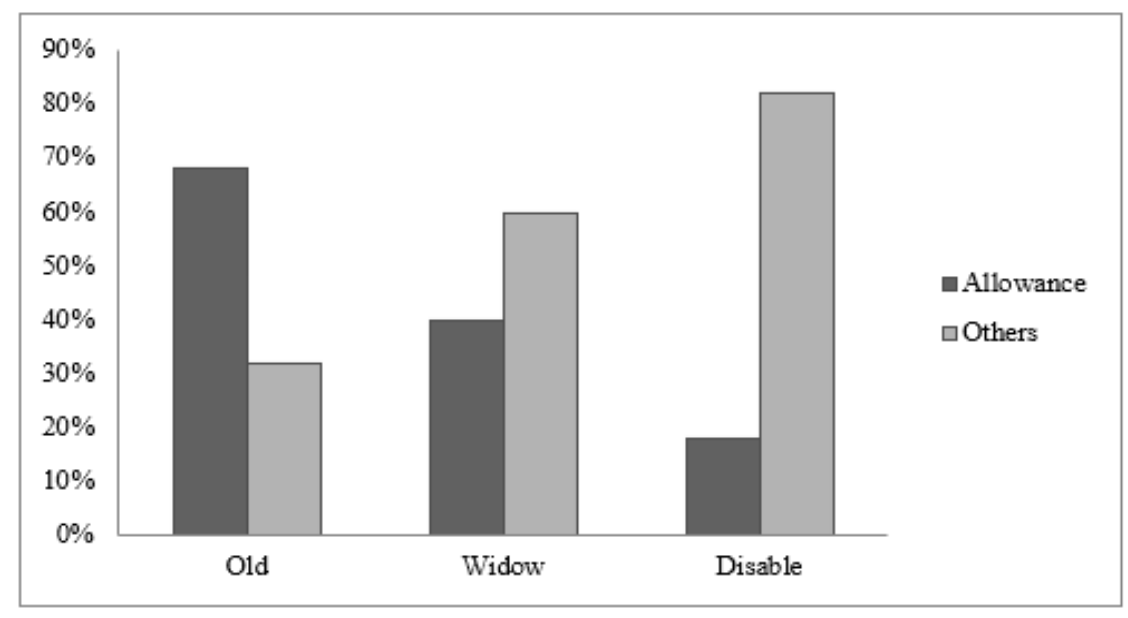

(Source: Field Survey, 2018).

Figure-9. Source of money for buying cloth

\subsection{Allowance and Social Resilience}

Through the grant is not enough to contribute to remove the extreme poverty level in terms of average monthly income. By this process, allowance may contribute to make a strong relationship among the risky poor beneficiaries in the society. Through this process now they become socially resilient.

\subsubsection{Beneficiary Selection and Social Relation}

The Union Parishad (UP) is responsible for the selection of beneficiaries based on criteria. It was found that for over 4 years no new allowance cards were issued. Every year the UP authority is sending a waiting list to the Upazila authority. With the death of a recipient, a new beneficiary is entering the final list. So, there is always a deficit of cards which insist the extreme poor to use social relationships and lobby with the local government. I found most beneficiaries did not need to spend money, but rather their social relationships played a key role of being selected. One independent elderly recipient said: "When I used to work as a labourer at the UP member's house, he was a child. All the family members always supported me in times of crisis. After becoming a member, I directly lobbied to the UP member. Finally he issued an old allowance card because of my persistence." There are many examples like this which also play an important role in building a relationship with the social elites.

\subsubsection{Intra-Household Relationships}

The elder beneficiaries uphold their state that if they earn enough, it is not necessary for them to relay much upon their children. They also narrate that their children are not able to take proper care of them when they are not able to earn. Many of them also think that their son's income is poor to maintain their own family. Therefore, it is not possible for them to bear their parents expenses. Here in the context, all beneficiaries explained that this allowance money which they receive plays an important role in the improvement of their relationship \& importance amongst their family members. Most of them noticed that their dignity has been increased by this program (Figure 10). Before getting the allowance they were no treated well. They were considered as burden \& valueless person among the family for not contribution. But nowadays the view has changed. At least one of the family members needs their allowance \& they didn't have to depend on others. On the contrary, they now can actively participate in decision-making process in the family (Figure 11). So, their importance has been increased in family as well as community.

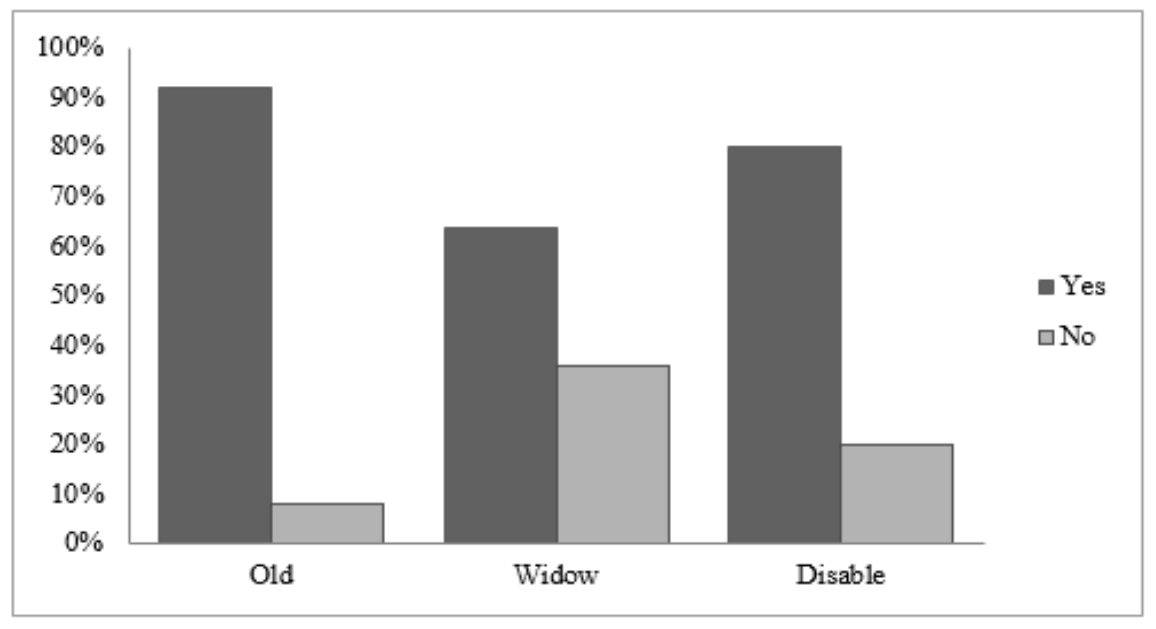

Figure-10. Increasing of dignity status of the respondents

Source: Field Survey, 2018). 
One of the old allowance recipients said: "I have been receiving this allowance for 17 months (sixth time). Before receiving this allowance I had to ask for money from my sons for my personal expenses, like going to my daughter's house, buying sweets even for buying medicine. But now I can spend it myself to buy medicines for my wife, to visit my daughter, to buy food for my grandchildren and for other personal expenses. This has lessened the burden of my sons which makes their wives happier".

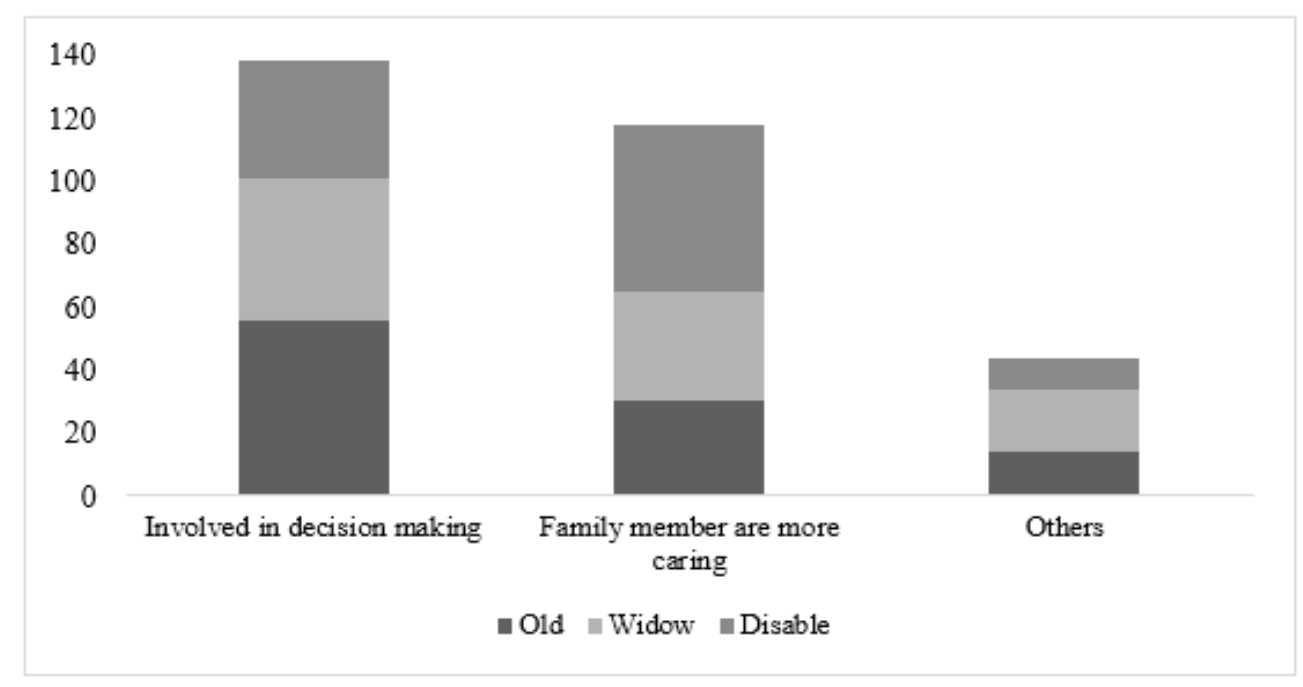

(Source: Field Survey, 2018).

Figure-1 1. Increasing of dignity status of the old respondents

Hospitality for their daughters' families in any occasion is very important to them. But they cannot do it when they become older and are unable to earn. As a result, the daughters may be humiliated at their in-laws' houses. So when they get the money, they can fulfill their wish and favour their daughter. A widow allowance receiver said, "After last Eid, my daughter came with her son at my place. I eat at the houses of my three sons in a cyclic order. I observed that none of them cooked meat for them. When my daughter goes back, if her in-laws find out that they had not been served meat, they would humiliate her. So, to protect my daughter's dignity, I bought poultry bird on credit. I told the shopkeeper that I will pay the amount after getting the allowance". The example shows how a widow protected his daughter's dignity by getting meat with the allowance money.

\subsubsection{Horizontal Relationships among the Recipients}

Although the village people have a good effective relationship based on the social activeness and on their geographical location, they have raised their social identity as recipient of allowance. As beneficiaries recipient they are now able to participate in allowance giving event every three months which strengthens relationships amongst them. So, this relationship could be considered a coping strategy to contribute to the resiliency of the recipients' households. A widow beneficiary explained that "I come to the bank several times with my neighbor and we share our life style. Now we had a good relation with them. And even now I am introduced with a lot of people who were unknown to me because of this allowance."

\subsubsection{Vertical Relationships among Recipients}

The villagers who live on below on the poverty line have to live on khas land by migrating from other areas. Usually khas land is a large unit of land that covers a number of households. So, the khas land people become a sub group in the community. On the contrary, although living in the same community, the local elites and extreme poor are in a relationship gap. I found that the strategy of repeated direct lobbying led to an allowance card. The beneficiaries uphold a connection to the local government through different ways which is the strongest vertical relationship. One of the disability allowance recipients said, "Once I am enlisted in the register book of the Government, I will get different support till death. Look, why did the people come to me? Just because I am enlisted in the Government register book."

After receiving disability allowance the recipients were found to be members of the disabled association at District level. This District level platform makes them more aware and informs on their rights and access to other GO-NGO initiatives. As a result the relationship between the upper class people contributing to building the resilience of the extreme poor recipients. Nowadays they are able to cope with any type of crisis as if through social inclusion and more support during hardship, thus, influencing horizontal relationships as well. The above discussion emphasis that the beneficiaries allowance builds the ability of the extreme poor recipients to create the space for better intra-household, horizontal and vertical relationships which contribute to integrating the poor into social structures and thus, build their resilience. 


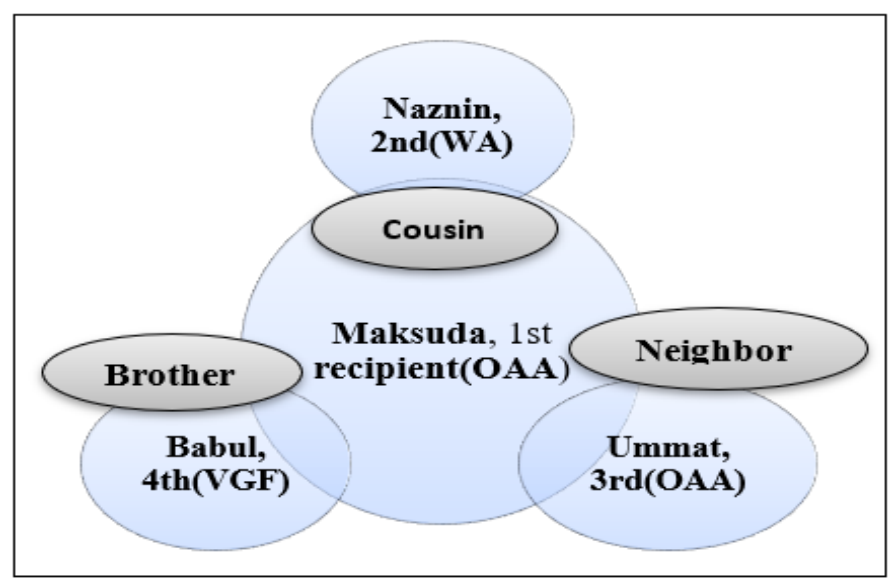

Figure-12. Relationship among the beneficiaries due to the program (Source: Field Survey, 2018).

Social safety net plays an important role making strong social relation among the community people. As a result the relationship becomes strong among them which help to maintain the disaster risk management. For example, on 2008 Maksuda Begum was selected as old age allowance beneficiaries by Upazilla parishad. In spite of being illiterate \& above 70, she was quite active and able communicated with Chairman, Member \& TNO to discuss about their problems. So, she was used to get invited by Upazilla chairman to give speech as the representative of beneficiaries in varies programmes. Her cousin Naznin was a widow and it was not possible for her to maintain her family. Naznin had two school going children. Afterwards Maksuda Begum requested Upazilla chairman to select Naznin as widow allowance beneficiaries \& Chairman approved it. Maksuda Begum's very close neighbor Ummat Ali came and requisted to help him to get any government allowance from union parishad. On 2011 he was also got selected as old allowance beneficiary because of Maksuda Begum. Maksuda Begum's younger brother Babul is a disable. For which he was not able to contribute economically in his family. To decrease his burden Maksuda begum help him out to get selected as a VGF beneficiary. As all of their houses are close together \& all of their socio economic condition is similar, a good relationship has been formed among them. They share each other problems and even help each other economically. Even on last cyclone Mohsin when Babul's house was destroyed, other helped him by lending him money. Nowadays all of them are playing an important role on solving many of their social problems.

\subsubsection{Problems in Obtaining SSN Supports}

The FGD beneficiary participants identified some problems in obtaining the supports as shown in Table 1. About 58 percent of beneficiary participants informed that there was no problem in obtaining SSN supports (Table 1). However, other FGD participants identified some problems in obtaining SSN supports. Maximum beneficiaries highlight distance fact as their main problem. As example, who lived in village has to go town for receiving the allowance where his traveling cost is near about 100 taka. Who are disable or old they need one person extra for helping. Then the cost has been 200 taka. Corruption is a common problem in such program. The very small amount of money is also a major problem.

Table-1. Problems in obtaining SSN supports identified by the FGD participants

\begin{tabular}{l|l|l}
\hline Problems & Percent & Ranking \\
\hline Do not get money timely & 14 & 4 \\
\hline Corruption & 20 & 2 \\
\hline Small amount of money & 18 & 3 \\
\hline Go to distant bank for drawing & 42 & $\mathbf{1}$ \\
\hline Distribution System is very poor & 4 & 5 \\
\hline Opening bank account & 2 & 6 \\
\hline Source: Field Survey, 2018 &
\end{tabular}

\subsubsection{Suggestions to Improve Effectiveness of the Existing SSNPs}

The FGD participants put some suggestions to improve effectiveness of the existing SSNPs which are presented in Table 2.

Table-2. FGD participants' suggestions to improve effectiveness of the existing SSNPs

\begin{tabular}{l|l|l}
\hline Suggestions & Percent & Ranking \\
\hline Distribution system should be easier & 6 & 5 \\
\hline The eligible family should be included & 2 & 6 \\
\hline To increase the number of beneficiary & 2 & 6 \\
\hline Drawing bank should be nearest & 24 & $\mathbf{2}$ \\
\hline Giving SSNPs support timely & 10 & 4 \\
\hline To reduce corruption & 18 & 3 \\
\hline To increase the amount of SSNP support & 38 & $\mathbf{1}$ \\
\hline Source: Field Survey, 2018 &
\end{tabular}




\section{Conclusion}

One of the main agenda of the government of Bangladesh is reduction of poverty. As in other developing countries, social safety net programmes (SSNPs) in Bangladesh can play a vital role in reducing poverty. During the last several decades many countries in the world have implemented a variety of such programmes to serve the vulnerable and underserved people as means of protection as well as promotion. It also helps to make them resilient socially and economically. The main success of this program lies in the fact that the beneficiaries have been able to improve their socio-economic condition with positive impact on income, food consumption and other basic needs. In addition, there have been positive changes in the quality of life of the members compared to the situation before joining the program. Their social relationship also has been increased due to the programe. Such social bonding is really helpful to cope up any natural disaster. Finally SSNs program really contribute to make these vulnerable community to turn resiliency.

\section{References}

Ahmed, S.S., 2005. Delivery mechanisms of cash transfer programs to the poor in Bangladesh. Washington DC: Human Development Network, World Bank.

Ahrc, 2010. Corruption promotes food and health insecurity for elderly widows in Northern Bangladesh. Asian Human Rights Commission Report, Asian Legal Resource Centre (Alrc).

Barkat, A., A. Karim and A.A. Hussain, 2011. Social protection measures In Bangladesh: As means to improve child well-being. Dhaka: Pathak Samabesh.

Begum, I. and S. Akter, 2014. Social safety nets and productive outcomes: Evidence and implications for Bangladesh. Mymensingh: Faculty of Agricultural Economics and Rural Sociolog, Bangladesh Agricultural University.

Hies, 2010. Report on Household Income and Expenditure Survey, Bangladesh Bureau of Statistics, Ministry of Planning, the Government of the Peoples Republic, Bangladesh.

Khan, N., 2012. An assessment of widow allowance programme in Bangladesh -the supply side perspectives. Bangladesh: Department of General and Continuing Education North South University.

Khuda, B., 2011. Social safety net programmes in Bangladesh: A review. Bangladesh Development Studies, 34(2): 87-108. View at Google Scholar Maniruzzaman, M., 2009. Management of selected social safety net programmes in the vulnerable Charlands of Bangladesh. Center for Agriresearch and Sustainable Environment \& Entrepreneurship Development (Caseed) and Cinishpur Dipsikha Mohila Somiti (Cdms). Retrieved from http://fpmu.gov.bd/agridrupal/sites/default/files/CF_1_of_07_Final_report__Approved_2.pdf.

Mannan, M.A. and B. Ahmed, 2012. Impact evaluation of vulnerable group development (Vgd) program in Bangladesh. Bangladesh Institute of Development Studies.

Mazmanian, D.A. and P.A. Sabatier, 1981. Effective policy implementation. Lexington, Ma: Lexington Books.

Uddin, A., 2013. Social safety nets in Bangladesh: An analysis of impact of old Age allowance program. Dhaka, Bangladesh: Institute of Governance Studies (Igs) Brac University.

World Bank, 2008. Poverty assessment for bangladesh: Creating opportunities and bridging the East-West divide. World Bank Bangladesh Development Series, Paper No. 2. 